\title{
EMPIRICAL VALUE RELEVANCE OF GERMAN GAAP AND IFRS
}

\author{
H Alexander Schiebel \\ Vienna University of Economics and Business Administration \\ alexander.schiebel@wu-wien.ac.at
}

August 2007

\begin{abstract}
It seems logical to assume that GAAP aimed at informing investors show a higher association with share prices (value relevance) than GAAP aimed at protecting creditors. The majority of empirical studies support this assumption. This paper examines the value relevance of IFRS and German GAAP. Regression analyses are applied to companies listed on the Frankfurt Stock Exchange and publishing exclusively either IFRS or German GAAP consolidated financial reports over the period 2000-2004. As a result of Regulation (EC) No 1606/2002, comparative research becomes impossible after 2004: German GAAP will no longer exist on European stock exchanges. The paper's study is restricted to a single capital market in order to eliminate pricing differences between capital markets based in different countries that have already been done in earlier research. Improved circumstances for investigating value relevance compared with earlier research are, however, the selection criteria for the listed companies (emphasis on international transparency requirements, free float and free float market capitalisation) and the share prices used (average price around the end of the business year when the financial reporting data is not yet published). The results of the study show that German GAAP is statistically more value relevant than IFRS. These results have to be interpreted in the light of the selection criteria. It is an unexpected outcome calling for further research.
\end{abstract}

Keywords:

Conservatism, German GAAP, IFRS, capital market, value relevance 


\section{INTRODUCTION}

International Financial Reporting Standards (IFRS) are commonly said to provide stakeholders in a company with information about its future cash flows at a specific point in time, typically the end of a company's business year (IASB Framework 16). Among those stakeholders, equity investors are considered to be the common denominator when deciding to whom the information should primarily be addressed (IASB Framework 10). This investor orientation is also intended to satisfy the information needs of other stakeholders (e.g., creditors). IFRS neither fulfils the function of determining the maximum dividends for a given business year nor does it provide the base for the computation of income taxes; this holds good for the economic and legal entity. Conservatism, or prudence, is far from being their driving principle: quite to the contrary, it is merely one principle among many, and only comes to the fore in certain cases (IASB Framework 37).

IFRS typically focuses, it is said, on transmitting the true and fair view on large, listed limited companies, the majority of whose equity is freely tradable, and whose fund-raising focuses on equity. Dumontier and Raffournier (1998) investigated the reasons for voluntarily complying with IFRS for a sample of Swiss listed companies. Their analyses showed that characteristics such as internationalism, ownership diffusion, and size correlate positively with voluntary compliance with IFRS. Other studies, however, did not support a positive correlation of ownership diffusion and voluntary compliance with IFRS (see Raffournier, 1995 and Wallace \& Naser, 1995). As a general rule, though, financial reports gain in importance when ownership diffusion or the free float is high, since few small shareholders have large budgets to spend on looking for "better" information (see Epstein \& Pava, 1994 and Anderson \& Epstein, 1995).

Within the International Accounting Standards Board (IASB) there has been a recent surge of enthusiasm for fair value measurement of assets and liabilities, together with an apparently linked movement towards more flexible asset recognition. Recent IASB publications such as the discussion paper "Measurement Bases for Financial Accounting - Measurement on Initial Recognition" (November 2005), prepared by the Canadian Accounting Standards Board (CASB), illustrate this tendency, because the paper recommends measuring all assets and liabilities at their fair values on initial recognition. Although the paper explicitly argues that this fair value recommendation is not considered to prejudice the subsequent measurement of assets and liabilities, it is most unlikely that the fair value movement will not affect aspects of subsequent measurement. Other recent IASB publications, such as the proposed amendments to IFRS 3 "Business Combinations" (June 2005), intend to make asset recognition in accounting for business combinations less restrictive in future. The idea is to present as many future net cash inflows of the company as possible as separable assets (resources) in the balance sheet. It remains to be seen whether these more relaxed proposed amendments for asset recognition will find their way into the IASB Framework or IFRSs as well. The IASB never tires of emphasising that the presentation of relevant and reliable information (about future cash flows as measured at a specific point in time) to shareholders or prospective investors is the reason for such developments.

Financial reporting based on German GAAP ${ }^{1}$ favours creditor protection over investor orientation and thus pays less attention to future cash flows than IFRS. German GAAP both determines the maximum amount of dividends payable per business year, and also serves as the base for the computation of income taxes for companies. This is said to lead to more conservative financial 
reporting for companies, with a lack of focus on financial reporting information enabling shareholders or prospective investors to predict future cash flows. German consolidation principles mean that this conservatism finds its way into German GAAP consolidated financial reports even though they do not have dividend limitation or tax functions.

The typical socio-economic environment of German limited companies under German GAAP is reputedly quite different from the typical IFRS one: very few shareholders for each limited company, who are usually the managers at the same time, relative insignificance of equity finance, great importance of long-term bank lending, so that banks are accustomed to exerting a decisive influence over companies' policies, and a major role, enshrined in statute, for employees. These characteristics, combined with the dividend limitation and tax functions of German GAAP in the case of limited companies, are the historical reasons for conservative financial reporting.

This paper will compare the value relevance of consolidated equity book values under German GAAP and IFRS for the market capitalisations of a sample of listed companies. The paper will hypothesise that investor-orientated GAAP should produce consolidated equity book values more closely related to market capitalisations under specific circumstances than creditororientated (conservative) GAAP. The basic question in this regard is: when can market capitalisations be regarded as benchmarks for the degree to which GAAP measures future cash flows attributable to shareholders or prospective investors in a listed company? There is abundant research on the subject. The core criticism is that theories of financial reporting underlying the inferences of that research are not descriptive of financial reporting, and thus the inferences must be invalid (see Holthausen \& Watts, 2001). In deference to this criticism, I shall try to make only valid inferences.

This paper proceeds as follows: part 2 describes the fundamental objectives of IFRS and German GAAP financial reporting that constitute the descriptive theory of financial reporting underlying the inferences. Part 3 provides a review - not intended to be exhaustive - of previous empirical market research into the value relevance of (different) GAAP. Part 4 develops the two hypotheses. Part 5 explains the sample selection procedure and describes the panel data used. Part 6 presents the research design together with the results of the empirical analyses. Finally, part 7 summarises the main findings.

\section{DESCRIPTIVE THEORIES OF FINANCIAL REPORTING}

\subsection{IFRS}

The fundamental objectives of IFRS financial reporting are set out in the IASB Framework. A recent IASB publication, the discussion paper "Measurement Bases for Financial Accounting Measurement on Initial Recognition" (November 2005), deals intensively with the fundamental objectives of IFRS financial reporting in accordance with the IASB Framework, in order to then draw conclusions about the most consistent measurement base for the initial recognition of assets and liabilities. The timing of this debate means that the paper can be used to present the descriptive theory of IFRS financial reporting.

The discussion paper mentions as the key aspects of the IASB Framework the economic purposes of financial reporting and their embodiment in assets and liabilities. I consider the following three sentences of paragraphs 47 to 49 crucial to an understanding of the link between the 
relevant information content of future net cash-equivalent flows of the entity as a whole and the relevant information content of future net cash-equivalent flows of individual assets and liabilities':

[...] Although investors and creditors are generally interested in net cash-equivalent flows of the entity as a whole, [...] those amounts are the aggregate of a number of individual cashequivalent flows related to individual assets and liabilities, or related groups of assets and liabilities, within the entity. [...] Thus, information on the amounts (value), timing and uncertainty of cash-equivalent flows is considered to be the primary focus of financial accounting. [...] The relationship between the expected cash-equivalent flows of an entity as a whole, or of business segments, and the contribution of individual assets and liabilities to those flows is a complex issue [...].

On the basis of these key aspects the discussion paper concludes that the market measurement of assets and liabilities on initial recognition prevails over the entity-specific measurement in terms of informing investors and creditors about future net cash-equivalent flows of the entity as a whole. Finally, it identifies the fair values of assets and liabilities as being most consistent with this market measurement objective.

It should be noted that the discussion paper's conclusions are preliminary. What these conclusions do highlight is IASB's intention to focus on the relevance of financial reports to financial statement users and - within this group - to shareholders or prospective investors as the common denominator: relevance in this connection means enabling shareholders or prospective investors to predict future net cash-equivalent flows of the entity as a whole in order to make decisions. This fundamental objective of IFRS financial reporting is used in this paper as the descriptive theory explaining the link between the market value of equity and the IFRS consolidated equity book value of a listed company under yet to be specified circumstances: if the equity book value approximates the company's market capitalisation, then the IASB will have succeeded in delivering information relevant to financial statement users. The circumstances to be specified mainly refer to allowing market capitalisation to be the benchmark that measures the degree to which IFRSs disclose future cash flows attributable to the shareholders or prospective investors in a listed company.

\subsection{German GAAP}

In 1995 the Working Group on External Financial Reporting of the Schmalenbach-Gesellschaft Deutsche Gesel/schaft für Betriebswirtschaft published a paper on German Accounting Principles (which I refer to as German GAAP). In this paper the Working Group establishes an organised framework, which can serve as a descriptive theory of German GAAP financial reporting. There is no equivalent to the IASB Framework in Germany. The Working Group contrasts German GAAP with Anglo-Saxon and international GAAP by presenting the typical German GAAP socio-economic environment from which the fundamental objectives of German GAAP financial reporting derive. Although the paper dates from 1995 and is now (2007) twelve years old, the fundamental objectives of German GAAP have not changed.

The paper describes the typical German GAAP socio-economic environment (1995:94-95). The paper then derives two fundamental objectives of German GAAP financial reporting as far as separate legal entities are concerned: creditor protection and the preservation of capital (1995:95). As far as the Working Group is concerned the preservation of capital supplements the objective of creditor protection because they both are intended to safeguard the company against the uncontrolled removal of assets by the shareholders (1995:95-96). The paper 
presents a further typical characteristic of German GAAP financial reporting for separate legal entities, serving as the base for the computation of income taxes. The paper does not call this link between financial and tax reports a fundamental objective of German GAAP financial reporting but another contributory factor to its conservatism (1995:97-98). Finally the paper states that the consolidated German GAAP financial reports are basically as conservative as the German GAAP financial reports for the separate legal entity (1995:99).

As this presentation of the fundamental objectives of German GAAP financial reporting shows, IFRS's fundamental objective of enabling shareholders or prospective investors to predict future net cash-equivalent flows of the entity as a whole in order to make decisions has no equivalent within the fundamental objectives of German GAAP. This missing fundamental objective of German GAAP financial reports is used in this paper as the descriptive theory predicting that the market value of equity should not necessarily be linked to the German GAAP consolidated equity book value of a listed company under yet to be specified circumstances. The circumstances to be specified mainly refer to allowing market capitalisation to be the benchmark that measures the degree to which German GAAP disclose future cash flows attributable to the shareholders or prospective investors in a listed company.

\section{LITERATURE REVIEW}

\subsection{Classification}

In 2001, Holthausen and Watts published a paper that simultaneously reviewed and criticised the value relevance literature up to 2001. I will employ the classification of Holthausen and Watts for this paper. First they grouped the papers they had reviewed into three types of studies:

- Relative association studies, which investigate the association of market capitalisations or changes thereof and financial reporting data generated under different GAAP over long periods of time (see, e.g., Beaver \& Dukes, 1972; Harris \& Ohlson, 1987; Alford, Jones, Leftwich \& Zmijewski, 1993; Pope \& Rees, 1993; Joos \& Lang, 1994; Harris, Lang \& Möller, 1994; Chan \& Seow, 1996; Biddle, Bowen \& Wallace, 1997; Bodnar \& Weintrop, 1997; Balsam \& Lipka, 1998; Dhaliwal, Subramanyam \& Trezevant, 1999; Harris \& Müller, 1999; Vincent, 1999; Bodnar, Hwang \& Weintrop, 2003; Bartov, Goldberg \& Kim, 2005).

- Incremental association studies, which investigate whether the financial reporting data of interest explains market capitalisations or changes thereof along with other financial reporting data over long periods of time (see, e.g., Shevlin, 1991; Barth, 1991; Barth, Beaver \& Stinson, 1991; Barth, Beaver \& Landsman, 1992; Amir, 1993; Barth \& McNichols, 1994; Barth, 1994; Amir, 1996; Barth, Beaver \& Landsman, 1996; Nelson, 1996; Choi, Collins \& Johnson, 1997; Ayers, 1998; Barth \& Clinch, 1996; Barth \& Clinch, 1998).

- Marginal information content studies, which investigate whether shareholders price in the financial reporting data of interest. Usually the association of the financial reporting data of interest and abnormal market capitalisation changes is investigated over short periods of time around the date of the financial reporting data's publication (see, e.g., Gheyara \& Boatsman, 1980; Beaver, Christie \& Griffin, 1980; Givoly \& Hayn, 1992; Amir, Harris \& Venuti, 1993; Bandyopadhyay, Hanna \& Richardson, 1994; Auer, 1996; Amir \& Lev, 1996).

Other classifications are similar to that of Holthausen \& Watts, though focusing on value relevance papers that have tried to make inferences about the prevailing value relevance of 
different GAAP. Bartov, Goldberg \& Kim (2005) wrote in this connection that the value relevance of different GAAP had been explored using either event study methodology (comparable to the marginal information content study of Holthausen \& Watts, 2001) or association study methodology (comparable to the relative association study of Holthausen \& Watts, 2001).

Holthausen \& Watts also classified the theories of financial reporting that underlay the value relevance literature up to 2001 and associated them with the types of studies they had identified, excluding marginal information content studies because of their postulated minor importance within the value relevance literature (2001:14-23):

- The direct valuation theory postulates that one objective of financial reporting is to generate equity book values or earnings that either measure or are strongly associated with market capitalisations or changes thereof. Relative association studies often consider this theory descriptive of financial reporting.

- The inputs-to-equity valuation theory postulates that one objective of financial reporting is to generate data that can serve as inputs to equity market valuation models. For this purpose a valuation model and the link between inputs of this model and the financial reporting data of interest are specified. Incremental association studies often consider this theory descriptive of financial reporting.

Holthausen \& Watts then classified the valuation models that had been used in the majority of cases in incremental association studies using the inputs-to-equity valuation theory (and to an extent in relative association studies using the direct valuation theory) (2001:52-63):

- The balance sheet model stipulates that the market value of equity equals the market value of all assets minus the market value of all liabilities within the balance sheet under specified assumptions. The idea is to pick out one asset or liability of interest and investigate its incremental association with the market capitalisation (see, e.g. Barth, 1991; Barth, Beaver \& Landsman, 1996). All future cash flows attributable to the shareholders of a listed company discounted with the appropriate cost of equity (the minimum return the shareholders require on their equity investment) must equal the net assets of that listed company in order for the balance sheet model to work. Thus, if any future cash flows attributable to the shareholders of a listed company have not been presented as market values of assets or liabilities in the balance sheet, then regressing the market value of equity on the equity book value will not result in a regression coefficient of one.

- The earnings model postulates that earnings are linked to the future cash flows of a listed company. Share returns or market capitalisations are therefore regressed on earnings or their components, and/or on changes in them (see, e.g., Barth, Beaver \& Landsman, 1992; Barth, 1994; Harris, Lang \& Möller, 1994; Barth \& Clinch, 1996; Dhaliwal, Subramanyam \& Trezevant, 1999; Bartov, Goldberg \& Kim, 2005).

- The Ohlson model (developed by Ohlson, 1991; Ohlson, 1995; Feltham \& Ohlson, 1995) postulates that the share price can be written as a linear function of earnings and equity book value, given a dividend valuation model and clean surplus accounting. The model provides a useful benchmark when one conceptualises how market value relates to financial reporting data and other information and was thus employed in a number of subsequent papers investigating the value relevance of financial reporting data (see, e.g. Harris, Lang \& Möller, 1994). It was first empirically investigated by Easton \& Harris (1991a), Penman (1991) and Maydew (1992). 


\subsection{Showcase relative association studies}

When researchers who investigated the value relevance of different GAAP chose a relative association study methodology instead of a marginal information content study, in a majority of cases they justified this choice by pointing to the possibility of dissemination of financial reporting data occurring prior to the announcement date (see, e.g., Harris, Lang \& Möller, 1994:194) or to problems of how exactly to determine earnings announcement dates (see, e.g., Bartov, Goldberg \& Kim, 2005:105). Consequently their decision depended on the feasibility of determining the point in time when the financial reporting data first became available to shareholders. But relative association studies were also dependent on the necessity of pairing stock exchange data and financial reporting data at the point in time when shareholders knew the financial reporting data, which is why this pairing in the majority of cases took place a few months after the end of the companies' business years.

Harris, Lang \& Möller (1994) published a relative association study with an underlying direct valuation theory (tested with the earnings and Ohlson model). They investigated the value relevance of financial reporting data of 230 German GAAP companies listing in Germany and 230 comparable US GAAP companies listing in the US over the ten-year period 1982-1991. The comparability was achieved by pairing German GAAP and US GAAP listed companies on the basis of industry affiliation (four-digit SIC code) and market capitalisation in the latest business year available (in general, 1991). The association of common share returns and common share prices with financial reporting data was tested and compared for the German GAAP and US GAAP sample. German GAAP and US GAAP sub-samples were also matched using their consolidation policy ("full consolidation", "domestic-only consolidation" and "unconsolidated") and tested for differences in the above associations.

The authors investigated panel data (observations on the same 460 companies over ten years). They paired financial reporting data with 18-month common share returns for the period starting at the beginning of the companies' business years, or with share prices six months after the end of the companies' business years in order to ensure that the financial reporting data was already available to the shareholders in the sample companies so that they could price them in. They investigated (among other things) two associations: they used a multiple linear regression analysis (earnings model) with the dependent variable "18-months common share return for the period starting at the beginning of the business year" and the two independent variables "annual movement of the reported earnings per outstanding share divided by the common share price at the beginning of the business year" and "reported earnings of the business year per outstanding share divided by the common share price at the beginning of the business year". Secondly, they employed a multiple linear regression analysis (Ohlson model) with the dependent variable "common share price six months after the business year" and the two independent variables "reported earnings of the business year per outstanding share" and "equity book value at the end of the business year per outstanding share".

In essence, they compared statistically the regression slopes of the German GAAP and US GAAP samples as measures of the GAAP's conservatism, and their coefficients of determination $\mathrm{R}^{2}$ as measures of the GAAP's value relevance. Harris, Lang \& Möller concluded with respect to the fully consolidated samples, first, that German GAAP could be seen as being more conservative than US GAAP and, second, that German GAAP and US GAAP reported earnings were approximately equally value relevant (earnings model), whereas German GAAP equity book values were less value relevant (Ohlson model). 
Bartov, Goldberg \& Kim (2005) published a relative association study with an underlying direct valuation theory (tested with the earnings model). They compared the value relevance of earnings reported under German GAAP, US GAAP, and IFRS by considering the association of share returns and reported earnings. The authors considered their restriction to one stock exchange a major advantage of their research compared to earlier research that had made cross-country value relevance comparisons of different GAAP (see for such a cross-country comparison Harris, Lang \& Möller, 1994). Their restriction meant that factors such as the legal and political environments, culture, macroeconomic conditions, and institutional arrangements were constant. Variations in these factors would have affected the results; the findings were thus more reliable.

Of other samples, one included 417 companies whose common shares listed on German Stock Exchanges during the period 1998-2000. These companies provided 915 fully consolidated financial reports covering 12 -month periods. In the course of the sample selection, missing and extreme observations (top or bottom $1 \%$ of the 12 -month share returns and earnings variables) were deleted. If a company had multiple issues of common shares, the authors considered the common share issue with the highest market capitalisation as the company's primary issue and used the return of that issue as their dependent variable for the regression analyses. The earnings and the share return data were taken from Global Vantage 2000. Within the 915 observations there were 680 German GAAP observations, 154 IFRS and 81 US GAAP ones. Of the German GAAP observations $90.74 \%$ came from the Frankfurt Stock Exchange, as did $63.64 \%$ of the IFRS and $51.85 \%$ of the US GAAP ones. The Neuer Markt was strongly represented within the IFRS (31.82\%) and US GAAP (45.68\%) observations.

The authors used two types of linear regression models: a cross-sectional model and a time series model ${ }^{3}$. Their cross-sectional model was a panel data analysis of the 417 companies mentioned above for the three-year period 1998-2000. It investigated whether the differences in the regression slopes of the German GAAP, US GAAP and IFRS sub-samples within the full sample were statistically significant. The dependent variable was 12 -month buy-and-hold share returns for the periods ending six months (or three months for the Neuer Markt companies) after the business years of the sample companies. The independent variable consisted of the reported earnings (income before extraordinary items) of the sample companies' business years divided by their market capitalisations (closing price of the companies' primary common share issue (see above) multiplied by the total number of shares outstanding) at the beginning of the sample companies' business years.

The cross-sectional model showed that both the US GAAP regression slope and the IFRS regression slope were to a statistically significant degree higher than the German GAAP regression slope. Bartov, Goldberg \& Kim (2005) considered these differences as proof of the theory that US GAAP and IFRS were more value relevant than German GAAP. Finally, they showed that their results held good only for profit observations, suggesting that GAAP did not have an influence on the quality of earnings in the case of loss observations.

\section{HYPOTHESES DEVELOPMENT}

One disadvantage of the showcase relative association studies is the pairing of financial reporting data with share prices or returns incorporating value relevant information at different points in time. Financial reporting data is published a few months after the end of the business year but incorporates the value relevant information as at the end of the business year. 
Measuring the responsiveness of shareholders to financial reporting data requires a comparison of financial reporting data with share prices or returns at the date of the data's publication. Consequently, the financial reporting data and the share prices or returns are based of necessity on different value relevant information.

I am interested in whether the shareholders' cash flow expectations at the end of the business year (share price) are measured by the consolidated financial reporting data at the end of the business year (equity book value) incorporating the management's cash flow expectations to the extent allowed by the GAAP used. Given this emphasis, it is indeed preferable that financial reporting data should not be available at the end of the sample companies' business years.

There is another weakness in the showcase relative association studies: trying to explain the market capitalisation on the basis of financial reporting data should mean establishing market capitalisation as the benchmark. The studies controlled neither for the immediate pricing in of newly published value relevant information by the shareholders nor for the timely availability of fresh value relevant information to the shareholders. Controlling for immediate pricing in would have meant ensuring that the stock exchange environment allowed, indeed virtually forced, the immediate pricing in of new value relevant information. To control for the timely availability of new value relevant information to the shareholders would have meant minimising information asymmetries between the shareholders and the management of the sample companies.

I wished to establish a benchmark market capitalisation under circumstances that minimise information asymmetries between shareholders and the management of the sample companies and allow the share price to be immediately influenced by newly published value relevant information. Why should the equity book value of a listed company assuming value relevant GAAP be close to its market capitalisation at the end of the company's business year if there are material information asymmetries between the two groups of stakeholders? Or why should this association occur if - in the absence of information asymmetries - the equally value relevant information available at the end of the company's business year did not immediately influence the share price, because of, e.g., a low free float and/or a low free float market capitalisation?

I conducted a relative association study employing the balance sheet model mentioned in part 3 in order to test the direct valuation theory developed in part 2. The market capitalisation of a company is similar to its DCF valuation, despite being embedded in an imperfect capital market. Basically, shareholders value a company as a whole, on the basis of their share of its discounted future cash flows. The equity book value as defined by German GAAP or IFRS also stems from a valuation of the company. Unlike the market capitalisation, though, the equity book value is the result of deducting the sum of all liabilities from the sum of all assets. Those assets and liabilities are valued separately, and affected by the valuation requirements inherent in the GAAP applied (e.g., cost model).

If a company were listed on a stock exchange in a perfect capital market, the DCF value of the company's equity would equal the market capitalisation at a given time. If a particular GAAP allowed all future cash flows of that company attributable to its shareholders to be presented as net assets in the balance sheet discounted with the appropriate cost of equity (what those shareholders require as a minimum of their equity investment), the company's equity book value would very definitely measure the market capitalisation at a given time. With perfect information efficiency the shareholders and the management of the company would share uniform future cash flow expectations and attribute the same commensurate risk to those future cash flows. 
Returning to imperfect capital markets but bearing in mind the above conclusion, I formulated a first general research design: a stock exchange environment that is as close as possible to a perfect market. Two related perfect market requirements are highly important in this connection: no information asymmetry between the company's management and its shareholders, and the guarantee that new value relevant information is priced into the share price immediately. I will approximate this stock exchange environment by selecting companies listing on a single stock exchange and in principle exhibiting three characteristics; while the first characteristic should minimise information asymmetries between the company's management and its shareholders, the other two characteristics should largely guarantee that new value relevant information is priced into the share price immediately:

- obeying international transparency requirements,

- having a substantial free float, and

- showing a substantial free float market capitalisation.

Next, I needed GAAP that are thought to be close to showing all future cash flows of that company attributable to its shareholders as net assets in the balance sheet discounted with the appropriate cost of equity. Based on the conclusions in part 2, I chose IFRS as an approximation for those GAAP. An analysis regressing market capitalisations on equity book values of companies listed on the selected stock exchange environment that use IFRS to arrive at their equity book values should produce a regression slope that is close to 1 . The market capitalisations and equity book values are paired at the end of the companies' business years.

There is an additional requirement, because my final goal is to compare the defined value relevance of different GAAP. I therefore increased the complexity by selecting another set of companies from the same stock exchange environment. This set differs from the first one because it employs different GAAP - ones that are assumed to be less value relevant because they do not come as close as IFRS to showing all future cash flows of that company attributable to its shareholders as net assets in the balance sheet discounted with the appropriate cost of equity. On the basis of the conclusions in part 2, I chose German GAAP as an approximation for those GAAP. The regression analysis described above is carried out with the German GAAP data. The absolute deviation of the resulting slope from 1 should be significantly higher than in the first regression analysis.

The hypothesis of IFRS's value relevance will be tested for two selected sets of companies listing on a single European stock exchange and publishing exclusively either German GAAP or IFRS consolidated financial reports over the period 2000-2004. This period covers the last five years during which this research is feasible: because of Regulation (EC) No 1606/2002, after 2004 German GAAP will no longer exist on European Stock Exchanges. The two samples will share the same stock exchange environment. If the slopes for German GAAP and IFRS are both to a statistically significant extent positive, the null hypothesis of the absence of value relevance of German GAAP and IFRS equity book values can be rejected. Thus, the first alternative hypothesis is:

$\mathrm{Hl}$ : The slopes of German GAAP and IFRS are both to a statistically significant extent positive.

If the German GAAP and IFRS companies are compared in terms of value relevance, the absolute deviation of the IFRS regression slope from 1 should be significantly lower statistically than the absolute deviation of the German GAAP slope from 1 . If this is the case, the null hypothesis of no 
value relevance difference between German GAAP and IFRS equity book values can be rejected in favour of the assumption that IFRS is more value relevant. Thus the second alternative hypothesis is:

The absolute deviation of the IFRS slope from 1 is to a statistically significant extent lower than the absolute deviation of the German GAAP slope from 1.

\section{SAMPLE SELECTION}

The requirement in the first instance is for a single European stock exchange with listed companies that make use on the one hand of German GAAP financial reporting and on the other hand of IFRS financial reporting. The restriction to one capital market eliminates pricing differences between capital markets in different countries (see Bartov, Goldberg \& Kim, 2005). In addition, only consolidated financial reports are of interest, because Harris, Lang \& Möller (1994) have shown that consolidated financial reporting data generally provides explanatory power (coefficient of determination) for share prices that is to a statistically significant extent higher than that of unconsolidated financial reporting data. Thus, I am looking for companies satisfying the following criterion 1 :

Criterion 1: Companies publishing German GAAP and IFRS consolidated financial reports the majority of whose shares are listed on the same European stock exchange.

I chose the Frankfurt Stock Exchange as this European Stock Exchange.

The sample must in principle be chosen on the basis of the three characteristics selected in part 4 , which I checked for at this stage in the sample selection procedure (see criterion 4 for the rest of the process). For the sake of simplicity, I checked for these characteristics only at the end of the research period 2000-2004. The companies and their shares listed on the Frankfurt Stock Exchange had to satisfy criterion 2 at the end of 2004 in order to be chosen:

Criterion 2: Companies that obey international transparency requirements and whose shares listed on the Frankfurt Stock Exchange have a high free float market capitalisation.

With different transparency standards, the Frankfurt Stock Exchange uses the scope available to it to create tailored legal frameworks for access to the capital market. Issuers in General Standard and Prime Standard fulfil the highest European transparency requirements. In Prime Standard, issuers must fulfil international transparency requirements that go beyond those of General Standard. Entry Standard provides small- to medium-sized companies, in particular, with an easy, fast and cost-efficient way to include their shares in exchange trading. The international transparency requirements of the Prime Standard include:

- quarterly reporting in German and English,

- application of international accounting standards (IFRS or US GAAP),

- publication of a financial calendar,

- staging of at least one analyst conference a year, and

- stock exchange announcements in English as well.

I restricted my study to the Prime Standard because of its demanding international transparency requirements, which mean that this segment has the greatest information efficiency and thus the lowest information asymmetries between the companies' management 
and its shareholders. On 30 December 2004 a total of 862 shares listed on the $\varepsilon U$-regulated Official Market or Regulated Market (369 shares in the Prime Standard and 493 shares in the General Standard).

Certain shares admitted to the Prime Standard are grouped in four selection indexes: DAX ${ }^{\circledR}$, $M D A X^{\circledast}, T e c D A X^{\oplus}$ and SDAX ${ }^{\oplus}$. I further restricted my investigation to companies whose shares were included in the selection indexes on 30 December 2004, in order to catch large and liquid share categories in terms of free float market capitalisation. This reduces the qualifying group to 160 shares.

The Frankfurt Stock Exchange regularly reviews the GAAP its Prime Standard companies employ in their published consolidated financial reports. The most recent review was on 30 June 2004, based on published consolidated financial reports then available $73 \%$ of the Prime Standard companies whose shares were included in the selection indexes were German parent companies; $7 \%$ were foreign parent companies. Of the German parent companies, $53 \%$ made use of IFRS, $27 \%$ of US GAAP and $20 \%$ of German GAAP .

I further restricted my study to German parent companies whose shares are listed in the selection indexes and which according to the review publish either IFRS or German GAAP consolidated financial reports. I wish to eliminate possible bias resulting from applying IFRS within different national GAAP cultures. This reduced the group to 109 shares. This restriction reduces the number of TecDAX ${ }^{\circledast}$ shares most severely, because of the dominant proportion of US GAAP companies in this selection index. The 109 shares belong to companies that therefore also satisfy the following criterion 3 :

Criterion 3: Companies that are German parent companies and publish German GAAP or IFRS consolidated financial reports according to the review of the Frankfurt Stock Exchange made as at 30 June 2004 on the basis of consolidated financial reports published at the time.

After this restriction, I tried to improve the stock exchange environment of the sample companies further in order to ensure that fresh value relevant information is priced into the share price immediately (see criterion 2 for the earlier use of this filter). Therefore I checked for two quantitative characteristics as at 30 December 2004 (free float exceeding $50 \%$ and free float market capitalisation exceeding EUR $100 \mathrm{~m}$ ). These characteristics held good for 61 shares, with the number of SDAX ${ }^{\circledast}$ shares being reduced most of all. This restriction is related to the following criterion 4 :

Criterion 4: Companies that have a free float exceeding $50 \%$ and a free float market capitalisation exceeding EUR $100 \mathrm{~m}$.

Finally, I took six shares out of the 61 because the issuing companies had their initial public offering after 2000; I am investigating the period 2000-2004 and need share prices for the whole of this period. I further restricted my study to those shares whose issuing companies published either IFRS or German GAAP consolidated financial reports exclusively for the entire period 2000 $2004^{9}$, leaving 35 shares in the sample. I excluded five preferred shares because of the way they are valued (see, e.g., Harris, Lang \& Möller, 1994, for an analogous exclusion), reducing the sample to 30 shares. Finally I excluded six shares whose issuing companies belong to the banking, insurance and financial services industries because of the particular financial reporting requirements of these industries. Thus the final criterion 5 that the sample companies had to satisfy is:

Criterion 5: Companies that have been listed since 2000, publishing exclusively either consolidated IFRS or German GAAP financial reports for the entire period 2000-2004," with common shares in 
issue exhibiting the criteria $1-4$, and not belonging to the banking, insurance or financial services industries.

\section{FIGURE 1: German GAAP and IFRS companies listing in one of the four Prime Standard selection indexes on 30 December 2004}

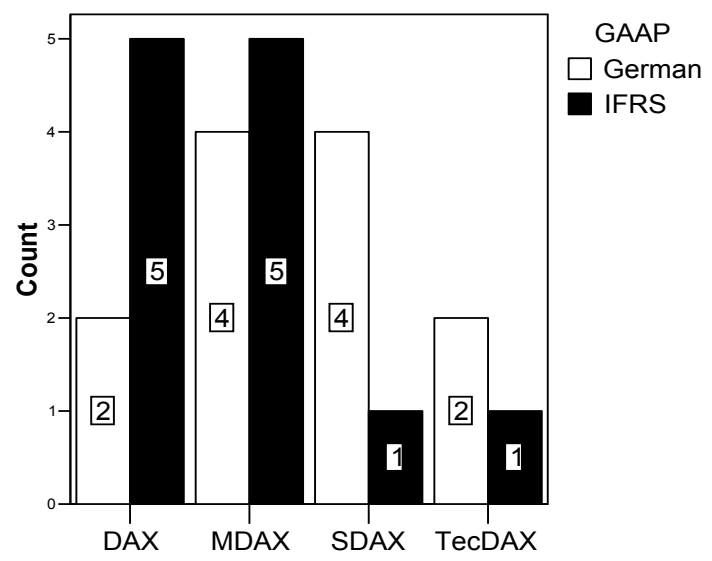

\section{Source: Eviews 5.1}

The final sample consists of 24 German parent companies that do not belong to the banking, insurance and financial services industries and whose common shares:

- were listed in the Prime Standard selection indexes on 30 December 2004,

- had a free float exceeding $50 \%$ on 30 December 2004 ,

- had a free float market capitalisation exceeding EUR $100 \mathrm{~m}$ on 30 December 2004, and

- have been listed on the Frankfurt Stock Exchange at least since 2000.

This final sample includes 12 companies publishing almost exclusively German GAAP consolidated financial reports for the entire period 2000-2004 (German GAAP sample) and 12 companies publishing exclusively IFRS consolidated financial reports for the entire period 2000-2004 (IFRS sample).

Two bar charts show the German GAAP and the IFRS samples listing in one of the four Prime Standard selection indexes on 30 December 2004 (FIGURE 1) and with a particular free float on 30 December 2004 (FIGURE 2). There are more DAX ${ }^{\circledast}$ and MDAX ${ }^{\circledast}$ shares in the IFRS sample than in the German GAAP one, and consequently more SDAX and TecDAX shares in the German GAAP sample. Of the IFRS shares, six show a free float exceeding $90 \%$, as do three German GAAP shares. There are five German GAAP shares and one IFRS share with a free float between $60 \%$ and $70 \%$.

FIGURE 2: German GAAP and IFRS companies with a free float exceeding the given percentages 


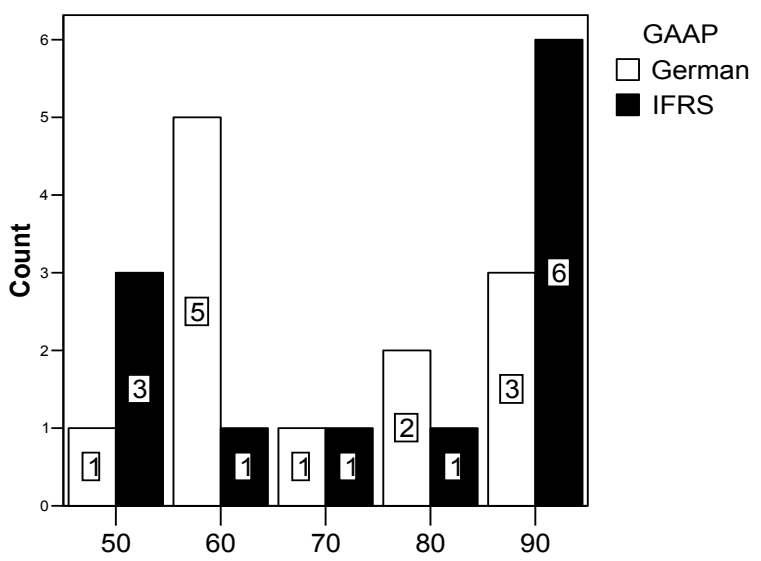

Source: Eviews 5.1

FIGURE 3: German GAAP and IFRS companies with a free float market capitalisation exceeding the given amounts ( $\varepsilon U R \mathrm{~m}$ ) on 30 December 2004

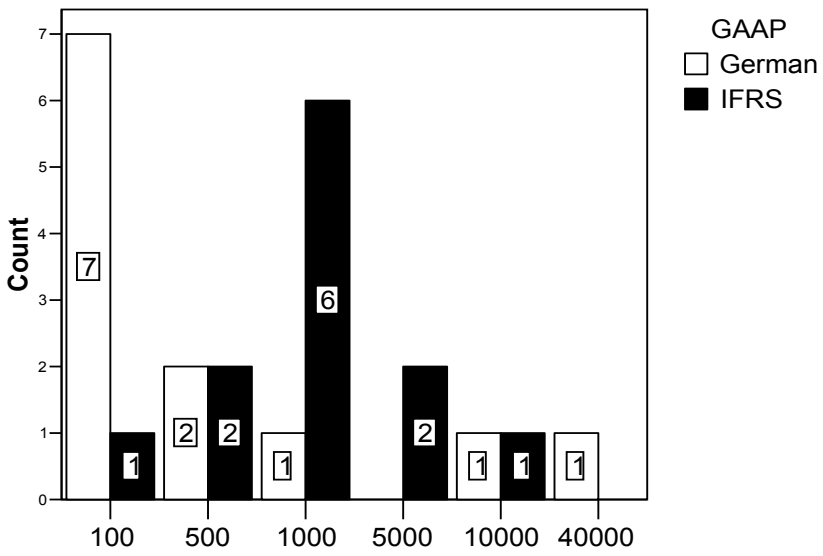

Source: Eviews 5.1

Further bar charts show the samples by free float market capitalisation on 30 December 2004 (FIGURE 3) and by industry (FIGURE 4). There are seven German GAAP shares and one IFRS share with a free float market capitalisation in the range EUR $100-500 \mathrm{~m}$, six IFRS shares and one German GAAP share with a free float market capitalisation in the range EUR $1000-5000 \mathrm{~m}$. IFRS has two shares with a free float market capitalisation in the range EUR $5000-10000 \mathrm{~m}$; 
German GAAP has none. The largest share in terms of free float market capitalisation is part of the German GAAP sample (exceeding EUR $40000 \mathrm{~m}$ ).

Looking at the industries in the two samples, a rather heterogeneous picture emerges: the basic resources, construction, pharma and healthcare, and transportation and logistics industries are represented in the IFRS sample, but not in the German GAAP sample. Retail and software industries are represented in the German GAAP sample, but not in the IFRS one. The industrial sector has six IFRS and only two German GAAP companies.

FIGURE 4: German GAAP and IFRS companies by industries

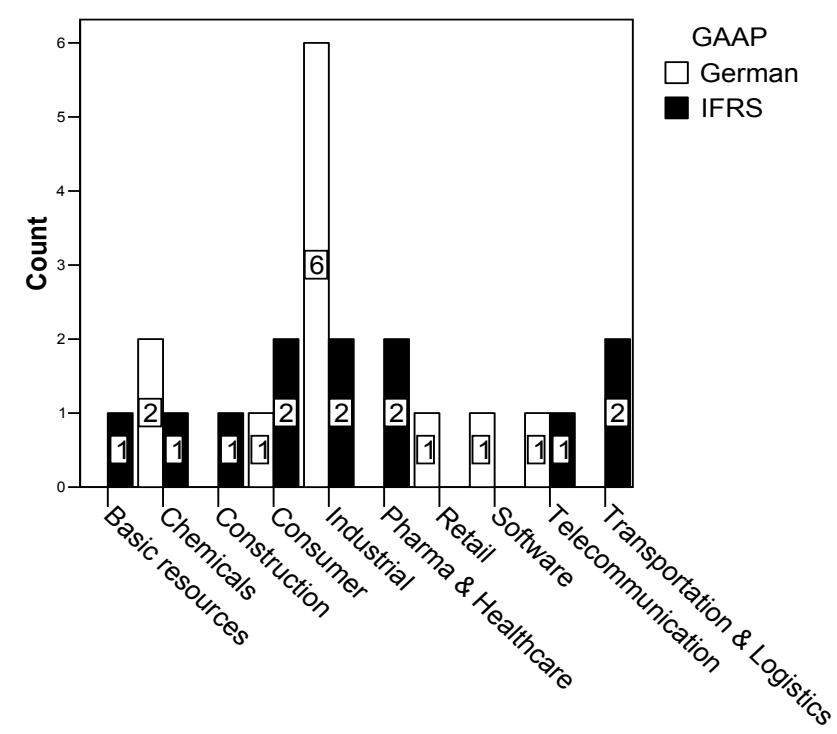

Source: Eviews 5.1

The analysis of the average free float and the average free float market capitalisation on 30 December 2004 of the shares selected shows that the IFRS shares have an average free float of $81.08 \%$ compared to the $74.83 \%$ for the German GAAP shares (see TABLE 1 ). This result is consonant with the results shown in FIGURE 2. The average free float market capitalisation of the German GAAP shares is EUR $6395,38 \mathrm{~m}$ compared with EUR $4217,99 \mathrm{~m}$ for the IFRS shares (see TABLE 1). 
TABLE 1: Descriptive statistics

\begin{tabular}{lccccc}
\hline & GAAP & $n$ & Mean & $\begin{array}{c}\text { Std. } \\
\text { deviation }\end{array}$ & $\begin{array}{c}\text { Std. error } \\
\text { mean }\end{array}$ \\
\hline Free float (\%) & German & 12 & 74.83 & 14.97 & 4.32 \\
Free float market & IFRS & 12 & 81.08 & 17.88 & 5.16 \\
capitalisation (EUR m) & German & 12 & 6395.38 & 14223.68 & $4,106.02$ \\
\hline
\end{tabular}

Source: Eviews 5.1

This outcome might be considered a little surprising, given the results shown in FIGURE 3. But bearing in mind the heavy weighting of one German GAAP share (free float market capitalisation of approximately EUR $40000 \mathrm{~m}$ ), it is not unreasonable. The t-tests for the equality of the average free float and the average free float market capitalisation on 30 December 2004 of the two (independent) samples show that there are no significant differences (see TABLE 2).

TABLE 2: $t$-test for the equality of the average free float and the average free float market capitalisation

\begin{tabular}{|c|c|c|c|c|c|c|c|c|}
\hline & & $\begin{array}{l}\text { Leve } \\
\text { fore }\end{array}$ & $\begin{array}{l}\text { s test } \\
\text { lity of }\end{array}$ & & $t-t e$ & for equa & of means & \\
\hline & & $F$ & Prob. & $t$ & $d f$ & $\begin{array}{l}\text { Prob. } \\
\text { (2- } \\
\text { tailed) }\end{array}$ & $\begin{array}{l}\text { Mean } \\
\text { diff. }\end{array}$ & $\begin{array}{c}\text { Std. error } \\
\text { diff. }\end{array}$ \\
\hline \multirow{2}{*}{$\begin{array}{l}\text { Free float } \\
(\%)\end{array}$} & $\begin{array}{l}\text { Equal var. } \\
\text { assumed }\end{array}$ & 1.53 & 0.23 & -0.93 & 22 & 0.36 & -6.25 & 6.73 \\
\hline & $\begin{array}{l}\text { Equal var. not } \\
\text { assumed }\end{array}$ & & & -0.93 & 21.34 & 0.36 & -6.25 & 6.73 \\
\hline \multirow{2}{*}{$\begin{array}{l}\text { Free float- } \\
\text { market cap. } \\
(\text { EUR m) }\end{array}$} & $\begin{array}{l}\text { Equal var. } \\
\text { assumed }\end{array}$ & 4.93 & 0.04 & 0.50 & 22 & 0.62 & 2177.39 & 4335.86 \\
\hline & $\begin{array}{l}\text { Equal var. not } \\
\text { assumed }\end{array}$ & & & 0.50 & 13.50 & 0.62 & 2177.39 & 4335.86 \\
\hline
\end{tabular}

Source: Eviews 5.1

\section{RESEARCH METHODS AND RESULTS}

I investigated whether market capitalisation MC, the dependent variable, is measured by the consolidated equity book value $S E$, the independent variable, for the German GAAP and the IFRS samples (see part 5) over the period 2000-2004. Thus I analysed panel data (observations on the same 24 companies over five years).

MC is derived by multiplying a Xetra ${ }^{\circledR}$ average share price of the selected share of a sample company towards the end of its business year by the total number of outstanding shares at the 
end of its business year. I simplified the investigation by only using Xetra ${ }^{\oplus}$ average share prices, thus substituting the average prices of shares being traded outside Xetra ${ }^{\circledR}$. This should not cause major distortions of the results, as the percentage of the number of outstanding shares not traded on the Xetra ${ }^{\oplus}$ platform is rather small. The Xetra ${ }^{\oplus}$ average share price is the average of the closing prices of 20 stock exchange days with the end of the business year located exactly in the middle of the period. This average is taken instead of the Xetra ${ }^{\circ}$ closing prices at the end of the business year or last stock exchange day before that date in order to smooth out aboveaverage movements of the Xetra ${ }^{\oplus}$ closing prices around the end of the business year as far as possible. All the data needed to calculate MC are taken from Reuters ${ }^{\circledR}$.

The consolidated equity book value $S E$ of a sample company at the end of its business year is based on either German GAAP or IFRS, excludes minority interests and is taken from Reuters ${ }^{\circledR}$. The market capitalisation only values those future cash flows attributable to the shareholders of the parent sample company, thus excluding the cash flows attributable to the minority shareholders in the parent sample company's subsidiaries.

There are the maximum 60 observations (12 companies, five years) for the IFRS sample and 56 observations for the German GAAP sample. Three companies published German GAAP consolidated financial reports for the period 2000-2003 and IFRS consolidated financial reports for the business year 2004. Those three companies remain within the German GAAP sample, excluding only the 2004 data and reducing the maximum observations to 57 . For one German GAAP sample company the consolidated financial reporting data of one year were missing, which further reduces the observations by one. The statistical software I used is Eviews 5.1. This software is specialised, among other things, in panel data analysis and thus most suitable for the task.

Test of H1: The German GAAP and the IFRS slope are significantly positive statistically.

I started by regressing the market capitalisation $M C$ on the consolidated equity book value $S E$ using the following simple linear regression analysis including all 24 sample companies:

$$
M C_{j t}=a 1 * S E_{j t}+a 2+R E S I D_{j t}
$$

where $\quad M C_{j t}$ is the market capitalisation of company $j$ around the end of its business year $t$.

$S \varepsilon_{\mathrm{jt}}$ is the consolidated equity book value excluding minority interests of company $j$ at the end of its business year $t$.

$R E S I D_{j t}$ is the residual term.

The Jarque-Bera (JB) test statistic (Jarque \& Bera, 1980) which can be used for models with a constant term equals $3,324.22$. Thus the probability that the JB null hypothesis of normally distributed residuals holds good is $0.00 \%$. A general heteroscedasticity test is White's test (White, 1980). It tests the homoscedasticity hypothesis against the alternative that heteroscedasticity is present, caused by the levels and squares of all explanatory variables. The test statistic "number of observations $n$ times coefficient of determination $\mathrm{R}^{2}$ of the auxiliary White regression analysis" is asymptotically chi-square distributed under the null hypothesis. In the case of the first regression analysis, the null hypothesis is rejected with a p value of 0.00 .

\section{TABLE 3: Regression analysis: Regressing MCjt on S\&jt - estimating panel (24 cross-sections included) ordinary least-squares - for 116 panel (unbalanced) observations}

\begin{tabular}{lllll}
\hline Variable & $a$ & Std. error & Tstatistic & Prob. \\
\hline
\end{tabular}




\begin{tabular}{lcccc}
\hline al*SE & 1.738957 & 0.055637 & 31.25569 & 0.0000 \\
a2 & -79214334 & $5.39 \varepsilon+08$ & -0.146859 & 0.8835 \\
\hline $\mathrm{R}^{2}$ & 0.895501 & Mean dependent var & $7.03 \varepsilon+09$ \\
Adjusted R & 0.894584 & S.D. dependent var & $1.62 \varepsilon+10$ \\
S.E. of regression & $5.27 \varepsilon+09$ & Akaike info criterion & 47.62486 \\
Sum squared resid & $3.16 \varepsilon+21$ & Schwarz criterion & 47.67233 \\
Log likelihood & -2760.242 & F statistic & 976.9179 \\
Durbin-Watson stat. & 2.128382 & Prob(F statistic) & 0.000000 \\
\hline
\end{tabular}

Source: Eviews 5.1

The Durbin-Watson statistic equals $2.13 ; \mathrm{d}_{1}=1.65$ and $\mathrm{d}_{\mathrm{u}}=1.69$ are tabulated for 100 observations, one independent variable and the significance level of $5 \%$. Thus the residuals are not autocorrelated.

Residuals that are not normally distributed and heteroscedastic can result if a linear regression model is estimated even though the regression relationship is not linear. If the data under study are time series of economic variables, such as consumption, income, or money, the regression relationship is often exponential: the data tends to grow exponentially over time. Taking logs in this case dampens the influence of large observations, especially if they are the result of a percentage increase on previous states - an exponential growth pattern.

The resulting log linear model often displays normal and homoscedastic residuals (see Newbold, Carlson \& Thorne, 2003:513). Taking logs is generally considered a permitted procedure to transform the data so that the assumptions of normal and homoscedastic residuals hold good (see Maddala, 2001:433).

Bearing in mind that the growth pattern of $M C_{j t}$ and $S \varepsilon_{j t}$ may possibly be exponential, as the probability of their general dependence on the overall growth per year of the German economy is high, I assumed the following simple exponential regression relationship instead, including all 24 sample companies (see Maddala, 2001:95 for a similar exponential regression relationship):

$$
M C_{j t}=A * S E_{j t}^{B} * R E S I D_{j t}^{U}
$$

I took logs of both sides and switch to the following simple linear regression analysis:

$$
\log \left(M C_{j t}\right)=\log (A)+B * \log \left(S E_{j t}\right)+U * \log \left(R E S I D_{j t}\right)
$$

Here the factor B can be interpreted as an elasticity. This form is called a double-log specification since it involves logs of both the dependent and the independent variable.

After defining

$$
B=b 1, \log (A)=b 2 \text { and } U * \log \left(R_{E S I D}\right)=\operatorname{RESID}_{j t}
$$


I had

$$
\log \left(M C_{j t}\right)=b 1 * \log \left(S E_{j t}\right)+b 2+R E S I D_{j t}
$$

The JB test statistic equals 0.94 . Thus the probability that the JB null hypothesis of normally distributed residuals holds good is $62.56 \%$. The White's test statistic equals 7.24 . The null hypothesis of homoscedastic residuals is rejected with a p value of $2.68 \%$. The Durbin-Watson statistic equals 0.51 . Thus the residuals are shown to be autocorrelated through data transformation by taking logs of both dependent and independent variables.

Evidence supporting normally distributed residuals is supplied by TABLE 4 . The probability of homoscedastic residuals is considerably increased; nevertheless the presence of homoscedastic residuals is still not conclusively demonstrated, because the data transformation resulted in the residuals becoming autocorrelated.

TABLE 4: Regression analysis: Regressing $\log (\mathrm{MCjt})$ on $\log (\mathrm{S} \varepsilon j \mathrm{j})$ - estimating panel (24 crosssections included) ordinary least squares - for 116-panel (unbalanced) observations

\begin{tabular}{lcllc}
\hline \multicolumn{1}{c}{ Variable } & $b$ & Std. error & Tstatistic & Prob. \\
\hline $\mathrm{b} 1^{\star} \log (\mathrm{SE})$ & 0.885352 & 0.035583 & 24.88162 & 0.0000 \\
$\mathrm{~b} 2$ & 2.875735 & 0.737849 & 3.897457 & 0.0002 \\
\hline $\mathrm{R}^{2}$ & 0.844495 & Mean dependent var. & 21.16930 \\
Adjusted $\mathrm{R}^{2}$ & 0.843131 & S.D. dependent var. & 1.690961 \\
S.E. of regression & 0.669734 & Akaike info criterion & 2.053219 \\
Sum squared resid & 51.13400 & Schwarz criterion & 2.100695 \\
Log likelihood & -117.0867 & F statistic & 619.0950 \\
Durbin-Watson stat & 0.511359 & Prob(F statistic) & 0.000000 \\
\hline
\end{tabular}

Source: Eviews 5.1

Controlling for outlying residuals may bring the residuals closer to normally distributed and homoscedastic ones (see Vogelvang, 2005:116, 160). TABLE 4 produces one residual as a near outlier $^{12}$. In order to achieve homoscedastic and normally distributed residuals, I excluded the observation causing the outlying residual and run equation (4) again with 115 observations (see TABLE 5).

The JB test statistic equals 0.67 . Thus the probability that the JB null hypothesis of normally distributed residuals holds good is $71.62 \%$. The White's test statistic now equals 0.98 . In the case of equation (4), after excluding the near outlier the null hypothesis of homoscedastic residuals is not rejected with a p value of $61.19 \%$. 
TABLE 5: Regression analysis: regressing $\log (\mathrm{MCjt})$ on $\log (\mathrm{S} \varepsilon j \mathrm{t})$ - estimating panel (24 crosssections included) ordinary least squares - for only 115-panel (unbalanced) observations resulting from exclusion of near outlier

\begin{tabular}{lcccc}
\hline \multicolumn{1}{c}{ Variable } & $c$ & Std. error & Tstatistic & Prob. \\
\hline $\mathrm{cl}^{\star} \log (\mathrm{S} \varepsilon)$ & 0.910548 & 0.034951 & 26.05179 & 0.0000 \\
$\mathrm{c2}$ & 2.336221 & 0.725896 & 3.218398 & 0.0017 \\
\hline $\mathrm{R}^{2}$ & 0.857268 & Mean dependent var & 21.18265 \\
Adjusted $\mathrm{R}^{2}$ & 0.856005 & S.D. dependent var & 1.692218 \\
S.E. of regression & 0.642140 & Akaike info criterion & 1.969217 \\
Sum squared resid & 46.59480 & Schwarz criterion & 2.016954 \\
Log likelihood & -111.2300 & F statistic & 678.6955 \\
Durbin-Watson stat & 0.455277 & Prob(F statistic) & 0.000000 \\
\hline
\end{tabular}

Source: Eviews 5.1

The first two assumptions of the ordinary least squares estimation method are accomplished by TABLE 5 after checking for outlying residuals, but the assumption of no autocorrelated residuals continues not to hold good. The related Durbin-Watson statistic equals 0.46 , still evidencing autocorrelation. Eviews 5.1 makes available a class of covariance structures within panel data analysis that allows for arbitrary period serial correlation and period heteroscedasticity between the residuals for a given cross-section, while restricting residuals in different crosssections to being uncorrelated. Employing these general least squares weights changes the Durbin-Watson test statistic to 2.09, no longer showing any evidence of autocorrelation (see TABLE 6).

TABLE 6: Regression analysis: Regressing $\log (\mathrm{MCjt})$ on $\log (\mathrm{S} \varepsilon j \mathrm{j})$ - estimating panel (24 crosssections included) general least squares (period of seemingly unrelated regression) for 115 (unbalanced) observations

\begin{tabular}{lrlcc}
\hline \multicolumn{1}{c}{ Variable } & $d$ & Std. error & t-statistic & Prob. \\
\hline $\mathrm{d} \mathrm{N}^{*} \log (\mathrm{S} \varepsilon)$ & 0.906370 & 0.055403 & 16.35967 & 0.0000 \\
$\mathrm{~d} 2$ & 2.467601 & 1.148270 & 2.148972 & 0.0338 \\
$\mathrm{R}^{2}$ & 0.982562 & Mean dependent var & 18.25723 \\
Adjusted R & & 7.198843 \\
S.E. of regression & 0.982408 & S.D. dependent var & 103.0202 \\
Durbin-Watson stat & 0.954821 & Sum squared resid & \\
\hline
\end{tabular}

Source: Eviews 5.1

I had to determine the German GAAP slope and the IFRS slope separately in order to test hypothesis $\mathrm{Hl}$. Thus, I determined equation (5) for the German GAAP sample and equation (6) for the IFRS one. I pooled these two regression equations into the multiple linear regression equation (7), differentiating between German GAAP and IFRS with the help of a dummy variable. 


$$
\begin{gathered}
\log \left(M C_{j t}\right)=\text { German } 1 * \log \left(S E_{j t}\right)+\text { German } 2+\operatorname{RESID}_{j t} \\
\log \left(M C_{j t}\right)=I F R S 1 * \log \left(S E_{j t}\right)+I F R S 2+\operatorname{RESID}_{j t} \\
\log \left(M C_{j t}\right)=e 1 * \log \left(S E_{j t}\right)+e 2 * \log \left(S E_{j t}\right) * G A A P_{j}+e 3 * G A A P_{j}+e 4+\operatorname{RESID}_{j t}
\end{gathered}
$$

where el is the German GAAP sample slope Germanl.

$\mathrm{el}+\mathrm{e} 2$ is the IFRS sample slope IFRSI.

e4 is the German GAAP sample constant term German2.

$\mathrm{e} 3+\mathrm{e} 4$ is the IFRS sample constant term IFRS2.

GAAP $_{j}$ is a dummy variable that equals 1 for IFRS and 0 for German GAAP.

I again used the class of covariance structures within the panel data analysis of Eviews 5.1 that allows for arbitrary period serial correlation and period heteroscedasticity between the residuals for a given cross-section, but restricts residuals in different cross-sections to being uncorrelated (see TABLE 7).

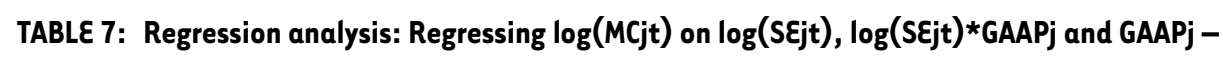
estimating panel ( 24 cross-sections included) general least squares (period of seemingly unrelated regression) - for 115 (unbalanced) observations

\begin{tabular}{lcccc}
\hline \multicolumn{1}{c}{ Variable } & $f$ & Std. error & Tstatistic & Prob. \\
\hline $\mathrm{fl} \log (\mathrm{S} \varepsilon)$ & 1.000911 & 0.067754 & 14.77269 & 0.0000 \\
$\mathrm{f} 2 \star \log (\mathrm{SE}) \star \mathrm{GAAP}$ & -0.275665 & 0.107306 & -2.568976 & 0.0115 \\
$\mathrm{f3}$ GAAP & 5.823886 & 2.232391 & 2.608810 & 0.0103 \\
$\mathrm{f} 4$ & 0.518743 & 1.371649 & 0.378189 & 0.7060 \\
\hline $\mathrm{R}^{2}$ & 0.978357 & Mean dependent var & 20.60007 \\
Adjusted $\mathrm{R}^{2}$ & 0.977772 & S.D. dependent var & 6.470630 \\
S.E. of regression & 0.964707 & Sum squared resid & \\
Durbin-Watson stat & 2.060395 & & \\
\hline
\end{tabular}

Source: Eviews 5.1

Now $\mathrm{Hl}$ can be tested for the German GAAP and IFRS sample. The German GAAP regression slope $\mathrm{fl}$ is 1.00 and statistically significant $(0.00 \%)$. The IFRS regression slope $f l+f 2$ is 0.73 and statistically significant ( $0.00 \%$ - see TABLE 8$)$. Thus the null hypothesis of the absence of value relevance of the present consolidated equity book values can be rejected for both the German GAAP and the IFRS sample. 
HA Schiebel

TABLE 8: Testing the IFRS sample slope $\mathrm{f} 1+\mathrm{f} 2$ whether equalling 0

\begin{tabular}{lccc}
\hline \multicolumn{1}{c}{ Wald test statistic } & Value & $d f$ & Probability \\
\hline F statistic & 75.96647 & $(1,111)$ & 0.0000 \\
Chi-square & 75.96647 & 1 & 0.0000 \\
& Normalised restriction $(=0)$ & Value & Std. err. \\
& $\mathrm{fl}+\mathrm{f2}$ & 0.725245 & 0.083210 \\
\hline
\end{tabular}

Source: Eviews 5.1

Statistically testing the constant term of the German GAAP and IFRS sample reveals a statistically significant difference $(0.05 \%)$ from 0 in the IFRS constant term ( $f 3+f 4)$ (see TABLE 9 ) but a statistically significant equality $(70.60 \%)$ of the German GAAP constant term $f 4$ and 0 which is shown by the $p$ value of $f 4$ in the regression analysis (TABLE 7).

TABLE 9: Testing whether the IFRS sample constant term $\mathrm{f} 3+\mathrm{f} 4$ equals 0

\begin{tabular}{lccc}
\hline \multicolumn{1}{c}{ Wald test statistic } & Value & $d f$ & Probability \\
\hline F-statistic & 12.96808 & $(1,111)$ & 0.0005 \\
Chi-square & 12.96808 & 1 & 0.0003 \\
& Normalised restriction $(=0)$ & Value & Std. err. \\
& $\mathrm{f3}+\mathrm{f4}$ & 6.342629 & 1.761292 \\
\hline
\end{tabular}

Source: Eviews 5.1

Test of H2: The absolute deviation of the IFRS slope from 1 is significantly lower statistically than the absolute deviation of the German GAAP slope from 1.

I first tested whether the German GAAP and the IFRS slope are significantly different statistically from 1 . The German GAAP slope $\mathrm{fl}$ equals 1 with a probability of $98.93 \%$ (see TABLE 10). The IFRS slope $\mathrm{fl}+\mathrm{f} 2$ equals 1 with a probability of $0.13 \%$ (see TABLE 11 ).

TABLE 10:Testing whether the German GAAP sample slope $f 1$ equals 1

\begin{tabular}{lccc}
\hline \multicolumn{1}{c}{ Wald test statistic } & Value & $d f$ & Probability \\
\hline Fstatistic & 0.000181 & $(1,111)$ & 0.9893 \\
Chi-square & 0.000181 & 1 & 0.9893 \\
& Normalised restriction $(=0)$ & Value & Std. err. \\
& $-1+f l$ & 0.000911 & 0.067754 \\
\hline
\end{tabular}

Source: Eviews 5.1 
TABLE 11:Testing whether the IFRS sample slope $f 1+f 2$ equals 1

\begin{tabular}{lccc}
\hline \multicolumn{1}{c}{ Wald test statistic } & Value & $d f$ & Probability \\
\hline F statistic & 10.90290 & $(1,111)$ & 0.0013 \\
Chi-square & 10.90290 & 1 & 0.0010 \\
& Normalised restriction $(=0)$ & Value & Std. err. \\
& $-1+f l+f 2$ & -0.274755 & 0.083210 \\
\hline
\end{tabular}

Source: Eviews 5.1

At this point the null hypothesis of $\mathrm{H} 2$ is already rejected. German GAAP and IFRS seem to be significantly different statistically in terms of value relevance as defined in part 4 . But it cannot be demonstrated that IFRS is better than German GAAP in terms of this value relevance. Under the very specified selection criteria used in this investigation, German GAAP consolidated equity book values seem to be significantly consonant statistically with the corresponding market capitalisations at the end of the companies' business years, whereas IFRS consolidated equity book values do not.

\section{SUMMARY}

In contrast to previous relative association studies, I have explored whether the shareholders' cash flow expectations (market capitalisations) at the end of the sample companies' business years were measured by the corresponding consolidated financial reporting data (equity book values) incorporating the management's cash flow expectations to the extent allowed by the GAAP used. I established a benchmark market capitalisation under terms that should minimise information asymmetries between the shareholders and the management of the sample companies and allow share prices to be immediately influenced by fresh value relevant information.

Value relevant financial reporting data was defined as follows: under perfect market conditions, the DCF value of a listed company's equity would equal its market capitalisation at a particular time. GAAP that allowed all future cash flows of that company attributable to its shareholders to be presented as net assets in the balance sheet discounted using the appropriate cost of equity (the minimum return shareholders demand on their equity investment) would bring the company's equity book value very close to its market capitalisation under perfect market conditions at a particular time.

I looked for a stock exchange environment with close-to-perfect market conditions so as to minimise information asymmetries between the company's management and its shareholders and ensure that fresh value relevant information was priced into the share price immediately. I then looked for GAAP that are thought to be close to presenting all future cash flows of a company attributable to its shareholders as net assets in the balance sheet discounted with the appropriate cost of equity. On the basis of the descriptive theory of IFRS financial reporting I chose IFRS as an approximation. An analysis regressing market capitalisations on IFRS consolidated equity book values of companies listing in this specific stock exchange environment was performed for the period 2000-2004.

The research design also required another set of companies from the same stock exchange 
environment. This set differed from the first one in using different GAAP; this GAAP was assumed to be less value relevant because it did not come so close to presenting all future cash flows of a company attributable to its shareholders as net assets in the balance sheet appropriately discounted as did IFRS. I chose German GAAP as an approximation, based upon the descriptive theory of German GAAP financial reporting. The regression analysis mentioned above was also carried out with the German GAAP data for the period 2000-2004.

The regression slopes were 1.00 for the German GAAP sample and 0.73 for the IFRS sample, making them highly significant statistically. The consolidated equity book values of both the German GAAP and the IFRS sample are thus value relevant. Nevertheless, the main hypothesis of a higher value relevance of IFRS consolidated equity book values could not be supported; quite to the contrary, it was shown that German GAAP exhibited a higher value relevance. It was hypothesised that perfect value relevance would have been demonstrable if the consolidated equity book values had been so close to the market capitalisations that a regression analysis with market capitalisations as the dependent and consolidated equity book values as the independent variable would have shown a regression slope not statistically significantly different from 1 . Considering that realistic market conditions and the GAAP employed by the sample companies would not have allowed such a perfect value relevance, another decision rule was formulated - to allow only comparative conclusions about the prevailing value relevance of certain GAAP, with those GAAP whose regression slope came nearest to 1 incorporating the highest value relevance.

Certain remarks have to be made about the chosen market capitalisations: there was the underlying assumption that the value relevant information the shareholders had at the end of the business years was comparable to what the management of the sample companies had at the same points. The specified selection criteria (see part 5) should have supported this assumption. The market capitalisations were taken as the benchmarks, and incorporated valuation details from Xetra ${ }^{\oplus}$, the trading platform from which the average share prices per common share for the sample companies came. As the regression slope of the IFRS sample was significantly lower statistically than 1 but significantly positive statistically, the market capitalisation increased (decreased) less when the IFRS consolidated equity book value increased (decreased). What should have been established was that the value relevant information the shareholders had at the end of the business years was comparable to what the management of the sample companies had at the same points; it does not follow from this that the GAAP used mirror this value relevant information.

The findings of this study are unexpected considering the opposite findings in the majority of previous empirical studies and the descriptive theories of German GAAP and IFRS; further research is thus called for. The hypotheses, sample selection procedure and research methods of this paper are possible starting points for further research.

\section{Acknowledgement}

This paper had been presented at the 29" Annual Congress of the European Accounting Association 2006, 22-24 March 2006, Dublin, Ireland; at the Emerging Issues in International Accounting and Business Conference 2006, 20-22 July 2006, Padova, Italy; at the 2"Annual Workshop on "Accounting in Europe Post 2005", 7-8 September 2006, Open University, Milton Keynes, UK; and at the 7"Annual Asian Academic Accounting Association Conference 2006, 17-19 September 2006, Sydney. I would like to thank the participants of these conferences for their valuable inputs. 


\section{REFERENCES}

Alford, A.; Jones, J.; Leftwich, R. \& Zmijewski, M. (1993). The Relative Informativeness of Accounting Disclosures in Different Countries. Journal of Accounting Research, Supplement, 31(3), pp. 183223.

Amir, ع. (1993). The Market Valuation of Accounting Information: The Case of Postretirement Benefits other than Pensions. Accounting Review, 68(4), pp. 703-724.

Amir, $\varepsilon$. (1996). The Effect of Accounting Aggregation on the Value-Relevance of Financial Disclosures: The Case of SFAS No. 106. Accounting Review, 71(4), pp. 573-590.

Amir, E.; Harris, T. S. \& Venuti, E. K. (1993). A Comparison of the Value-Relevance of U.S. versus NonU.S. GAAP Accounting Measures Using Form 20-F Reconciliations. Journa/ of Accounting Research, Supplement, 31(3), pp. 230-264.

Amir, \&. \& Lev, B. (1996). Value-relevance of nonfinancial information: The wireless communications industry. Journal of Accounting \& Economics, 22(1-3), pp. 3-30.

Anderson, R. \& Epstein, M. (1995). The usefulness on annual reports. Australian Accountant, 65(3), pp. 25-28.

Auer, K. (2003). Capital market reactions to earnings announcements: empirical evidence on the difference in the information content of IAS-based earnings and $\varepsilon C$-Directives-based earnings. European Accounting Review, 5(4), pp. 587-623.

Ayers, B. C. (1998). Deferred Tax Accounting Under SFAS No. 109: An Empirical Investigation of its Incremental Value-Relevance Relative to APB No. 11. Accounting Review, 73(2), pp. 195-212.

Balsam, St. \& Lipka, R. (1998). Share prices and alternative measures of earnings per share. Accounting Horizons, 12(3), pp. 234-249.

Bandyopadhyay, S. P.; Douglas Hanna J. \& Richardson, G. (1994). Capital Market Effects on U.S.Canada GAAP Differences. Journal of Accounting Research, 32(2), pp. 262-277.

Barth, M. E. (1991). Relative Measurement Errors Among Alternative Pension Asset and Liability Measures. Accounting Review, 66(3), pp. 433-463.

Barth, M. E. (1994). Fair Value Accounting: Evidence from Investment Securities and the Market Valuation of Banks. Accounting Review, 69(1), pp. 1-25.

Barth, M. E. \& Beaver, W. H. (1996). Value-Relevance of Banks' Fair Value Disclosures under SFAS No. 107. Accounting Review, 71(4), pp. 513-537.

Barth, M. E.; Beaver, W. H. \& Stinson, Ch. H. (1991). Supplemental data and the structure of thrift share prices. Accounting Review, 66(1), pp. 56-66.

Barth, M. દ. \& Clinch, G. (1996). International Accounting Differences and Their Relation to Share Prices: Evidence from U.K., Australian, and Canadian Firms. Contemporary Accounting Research, 13(1), pp. 135-170.

Barth, M. E. \& Clinch, G. (1998). Revalued Financial, Tangible, and Intangible Assets: Associations with Share Prices and Non-Market-Based Value Estimates. Journal of Accounting Research, Supplement, 36(3), pp. 199-233.

Barth, M. E. \& McNichols, M. F. (1994). Estimation and Market Valuation of Environmental Liabilities Relating to Superfund Sites. Journal of Accounting Research, Supplement, 32(3), pp. 177-209. 
Barth, M. \&; Beaver, W. H \& Landsman, W. R. (1992). The market valuation implications of net periodic pension cost components. Journal of Accounting \& Economics, 15(1), pp. 27-62.

Bartov, E., Goldberg, St. R. \& Kim, M. (2005). Comparative Value Relevance among German, U.S., and International Accounting Standards: A German Stock Market Perspective. Journal of Accounting, Auditing \& Finance, 20(2), pp. 95-119.

Beaver, W. H., Christie, A. A. \& Griffin, P. A. (1980). The Information Content of SEC Accounting Series Release No. 190. Journal of Accounting \& Economics, 2(2), pp. 127-157.

Beaver, W. H. \& Dukes, R. દ. (1992). Interperiod Tax Allocation, Earnings Expectations, and the Behavior of Security Prices. Accounting Review, 47(2), pp. 320-332.

Biddle, G. C., Bowen, R. M. \& Wallace, J. S. (1997). Does $E V A{ }^{\circledR}$ beat earnings? Evidence on associations with stock returns and firm values. Journal of Accounting \& Economics, 24(3), pp. 301-336.

Bodnar, G. M. \& Weintrop, J. (1997). The valuation of the foreign income of US multinational firms: a growth opportunities perspective. Journal of Accounting \& Economics, 24(1), pp. 69-97.

Bodnar, G. M, Hwang, L.-S. \& Weintrop, J. (2003). The Value Relevance of Foreign Income: an Australian, Canadian, and British Comparison. Journal of International Financial Management \& Accounting, 14(3), pp. 171-193.

Brosius, F. (2004). SPSS 12. Bonn: Verlag.

Chan, K. C. \& Seow, G. S. (1996). The association between stock returns and foreign GAAP earnings versus earnings adjusted to U.S. GAAP. Journal of Accounting \& Economics, 21 (1), pp. 139-158.

Choi, B., Collins, D. W. \& Johnson, W. B. (1997). Valuation implications of reliability differences: The case of nonpension postretirement obligations. Accounting Review, 72(3), pp. 351-383.

Dhaliwal, D., Subramanyam, K. R. \& Trezevant, R. (1999). Is comprehensive income superior to net income as a measure of firm performance? Journal of Accounting \& Economics, 26(1-3), pp. 4367.

Dumontier, P. \& Raffournier, B. (1998). Why Firms Comply Voluntarily with IAS: an Empirical Analysis with Swiss Data. Journal of International Financial Management and Accounting, 9(3), pp. 216 245.

Easton, P. D. \& Harris, T. S. (1991a). Empirical Evidence on the Relevance of Earnings and Book Value of Owners' Equity in Security Valuation. Working Paper, Columbia University.

Epstein, M. J. \& Pava, M. L. (1994). Individual investors' perceptions on the summary annual... Journal of Applied Business Research, 10(3), pp. 60-67.

Fisher, R. A. (1948). Statistical Methods for Research Workers, $10^{\text {th }}$ edition. Edinburgh: Oliver and Boyd.

Feltham, G. A. \& Ohlson, J. A. (1995). Valuation and Clean Surplus Accounting for Operating and Financial Activities. Contemporary Accounting Research, 11(2), pp. 689-731.

Gheyara, K. \& Boatsman, J. (1980). Market Reaction to the 1976 Replacement Cost Disclosures. Journal of Accounting \& Economics, 2(2), pp. 107-125.

Givoly, D. \& Hayn, C. (1992). The Valuation of the Deferred Tax Liability: Evidence from the Stock Market. Accounting Review, 67(2), pp. 394-410.

Harris, M. S \& Muller K. A (1999). The market valuation of IAS versus US-GAAP accounting measures using Form 20-F reconciliations. Journal of Accounting \& Economics, 26(1-3), pp. 285-312. 
Harris, T. S. \& Ohlson, J. A. (1987). Accounting Disclosures and the Market's Valuation of Oil and Gas Properties. Accounting Review, 62(4), pp. 651-671.

Harris, T. S., Lang, M. \& Möller, H., P. (1994). The Value Relevance of German Accounting Measures: An Empirical Analysis. Journal of Accounting Research, 32(2), pp. 187-209.

Holthausen, R. W. \& Watts, R. L. (2001). The relevance of the value-relevance literature for financial accounting standard setting. Journal of Accounting \& Economics, 31(1-3), pp. 3-75.

International Accounting Standards Board (IASB) (2005). Discussion Paper, Measurement Bases for Financial Accounting Measurement on Initial Recognition, Prepared by staff of the Canadian Accounting Standards Board. Available from: http://www.iasb.org/NR/rdonlyres/E1A542DB3A19-47AC-B995-EFCFA044F3EC/0/MeasurementBasesforFinancialAccountingDPfullversion.pdf (Accessed on 18 February 2008).

International Accounting Standards Board (IASB) (2005). Exposure Draft of Proposed Amendments to IFRS 3 Business Combinations. Available from: http://www.iasb.org/NR/rdonlyres/1C3066EC3FEF-4966-A42E-E8AC8F341869/0/Proposedamendtoifrs3.pdf (Accessed on 18 February 2008).

Jarque, C. M. \& Bera, A. K. (1980). Efficient Tests for Normality, Homoscedasticity and Serial Independence of Regression Residuals. Economics Letters 6, pp. 255-259.

Joos, P. \& Lang, M. (1994). The Effects of Accounting Diversity: Evidence from the European Union. Journal of Accounting Research, Supplement, 32(3), pp. 141-168.

Maddala, G.S. (2001). Introduction to Econometrics, $3^{d}$ edition. USA: John Wiley \& Sons.

Maydew, E. L. (1992). An Empirical Evaluation of Earnings and Book Values in Security Valuation (Working paper). lowa: University of lowa.

Nelson, K. K. (1996). Fair Value Accounting for Commercial Banks: An Empirical Analysis of SFAS No. 107. Accounting Review, 71(2), pp. 161-182.

Newbold, P., Carlson, W. L. \& Thorne, B. (2003). Statistics for Business and Economics, $5^{\text {th }}$ edition. New Jersey: Prentice Hall.

Ohlson, J. A. (1991). Earnings, Book Values, and Dividends in Security Valuation (Working Paper), New York: Columbia University.

Ohlson, J.A. (1995). Earnings, Book Values, and Dividends in Equity Valuation. Contemporary Accounting Research, 11(2), pp. 661-687.

Penman, S. H. (1991). An Evaluation of Accounting Rate of Return. Journal of Accounting, Auditing and Finance, 6(2), pp. 233-256.

Pope, P. F. \& Rees, W. P. (1993). International Differences in GAAP and the Pricing of Earnings. Journal of International Financial Management \& Accounting, 4(3), pp. 190-219.

Raffournier, B. (1995). The determinants of voluntary financial disclosure by Swiss listed companies. European Accounting Review, 4(2), pp. 261-280.

Shevlin, T. (1991). The Valuation of R\&D Firms with R\&D Limited Partnerships. Accounting Review, 66(1), pp. 1-21.

The Working Group on External Financial Reporting of the Schmalenbach-Gesellschaft-DeutscheGesellschaft für Betriebswirtschaft (1995). German Accounting Principles: An Institutionalized Framework. Accounting Horizons, 9(3), pp. 92-99. 
Vincent, L. (1999). The information content of funds from operations (FFO) for real estate investment trusts (REITs). Journal of Accounting \& Economics, 26(1-3), pp. 69-104.

Vogelvang, B. (2005). Econometrics - Theory and Applications with Eviews. Essex: Pearson Education.

Wallace, R. S. 0. \& Naser, K. (1995). Firm-Specific Determinants of the Comprehensiveness of Mandatory Disclosure in the Corporate Annual Reports of Firms Listed on the Stock Exchange of Hong Kong. Journal of Accounting and Public Policy, 14(4), pp. 312-369.

White, H. (1980). A Heteroscedasticity-consistent Covariance Matriy Matrix Estimator and a Direct Test for Heteroscedasticity. Econometrica 48, pp. 817-838.

The term "Generally Accepted Accounting Principles" ("GAAP") is not formally defined in Germany. Nevertheless, I use the term "German GAAP" throughout this paper to simplify terminology. Basically, German GAAP refers to financial reporting principles and regulations of the German Commercial Code.

Quotes are taken from the full version of this discussion paper, published on the IASB website. Available from:

http://www.iasb.org/NR/rdonlyres/E1A542DB-3A19-47AC-B995-

EFCA044F3EC/0/MeusurementBasesforFinancialAccountingDPfullversion.pdf (Accessed on 18 February 2008)

The time series model was used for a before-and-after comparison using a set of companies that had switched from German GAAP to either US GAAP or IFRS. Both the sample and the time period of this set differed from that of the cross-sectional model. As in the cross-sectional model, the time series model paired share returns and reported earnings at points in time when the reported earnings were already available to the shareholders. The results showed that switching to either US GAAP or IFRS resulted in a stronger association of share returns and reported earnings, indicating improved value relevance.

- It is interesting that Harris/Lang/Möller (1994) would have considered these results quite differently because they hypothesised that the GAAP exhibiting a statistically significantly higher regression slope were the more prudent ones.

- There are two points of access to the European capital market: access via markets regulated by the EU ( $(U$-regulated markets) and access via markets regulated by the stock exchanges themselves (regulated unofficial markets). At the Frankfurt Stock Exchange, a listing on the $\varepsilon U$-regulated Official Market or Regulated Market results in inclusion in the General Standard or its Prime Standard segment, while admission to trading on the Regulated Unofficial Market means inclusion in the Open Market with its Entry Standard segment.

DAX is the blue chip index and includes the thirty largest shares in terms of market capitalisation and order book turnover from classic and technology sectors. TecDAX is the selection index for mid-sized companies (mid caps) from technology sectors, starting directly below the DAX and including thirty shares. MDAX is the selection index for mid-sized companies (mid caps) from classic sectors, starting directly below the DAX and including fifty shares. SDAX is the selection index for smaller companies (small caps) from classic sectors, starting directly below the MDAX and including fifty shares.

The Prime Standard indexes are capital-weighted, i.e., the weighting of the shares is determined on the basis of the total capital of the shares contained in the index. On the chaining date in June 2002, the Frankfurt Stock Exchange converted the index calculation to a free float weighting basis, so that only the freely tradable portion of a company's stock in a given category is used to calculate its weighting in an index. Only the largest and most liquid share category is taken into account in the selection index. Trading volume and market capitalisation, on the basis of the number of shares in the free float, are the selection criteria for admission to a stock index.

Available from: http://deutsche- 
boerse.com/dbag/dispatch/de/binary/gdb_content_pool/imported_files/public_files/10_downloads/36 _reports_and_statistics/rechnungslegungsstandards160604.xls (Accessed on 18 February 2008).

- Clause 62(1)(1) and (2) of the Exchange Rules of the Frankfurt Stock Exchange require as a matter of principle the application of international accounting standards (IFRS or US GAAP) for Prime Standard companies. Clause 95 of these rules offers transitional provisions for certain companies: "With respect to issuers whose shares [...] are already quoted on the Frankfurt Stock Exchange as of January 1, 2003, the provisions pursuant to Clause 62(1)(1) and (2) [...] shall only apply for the financial year commencing on or after January 1, 2005." This is why several companies whose shares are listed in the Prime Standard were allowed to publish German GAAP consolidated financial reports until 2004.

- There are three exceptions to that rule: These three companies are publishing German GAAP consolidated financial reports for the period 2000-2003 and IFRS consolidated financial reports for the business year 2004. Those three companies remain in the sample excluding only the 2004 data.

"See note 9.

See note 9.

"The inner fences are defined as the first quartile minus 1.5 times its interquartile range (IQR) and the third quartile plus 1.5 times its IQR. Data points outside the inner fence are known as outliers. For greater discrimination of outliers, Eviews 5.1 defines the outer fences as the first quartile minus 3 times its IQR and the third quartile plus 3 times its IQR. Data between the inner and outer fences are termed near outliers, and those outside the outer fence are referred to as far outliers. 
HA Schiebel 